\title{
OKE MAS (Optimalisasi Kegiatan E-learning Menjadi Aktif dan Soluktif) Upaya Peningkatan Sektor Ekonomi dan Pendidikan di Masa Pandemi
}

\author{
Rudi Haryadi', Mochamad Wildan Al'ayubi ${ }^{2}$ \\ ${ }^{1}$ Pendidikan Fisika, Universitas Sultan Ageng Tirtayasa \\ ${ }^{2}$ Pendidikan Fisika, Universitas Sultan Ageng Tirtayasa
}

E-mail: ${ }^{1}$ rudiharyadi@untirta.ac.id , ${ }^{2}$ wildanalayubi64@gmail.com

\author{
\begin{tabular}{|l|l|l|}
\hline Receive: 12/10/2020 & Accepted: : 18/10/2020 & Published: : 30/10/2020
\end{tabular}
}

\begin{abstract}
Abstrak
Sesuai dengan Surat Edaran Mendikbud Nomor 4 Tahun 2020 tentang pelaksanaan kebijakan pendidikan dalam masa darurat penyebaran COVID 19 mengajurkan untuk melaksanakan proses belajar dari rumah melalui pembelajaran daring, kesiapan dari pihak penyedia layanan maupun siswa merupakan tuntutan dari pelaksanaan pembelajaran daring. Tentu tidak ada yang menginginkan ini semua terjadi. Namun atas kemanusian diatas segalanya, hal ini perlu di berlakukan dengan baik agar kita semua segera terbebas dari pandemi Covid-19. Sudah seharusnya peran milenial sangat intens diperlukan dalam menciptakan ide-ide dan trobosan untuk menstabilkan segala sektor saat masa pandemi seperi saat ini. Oleh karenanya penulis mencoba memberi suatu gagasan yang mungkin bisa dijadikan solusi dalam mangatasi masalah kususnya dalam sektor ekonomi maupun sektor pendidikan. Dengan program OKE MAS (Optimalisasi Kegiatan E-learning Menjadi Aktif dan Soluktif) dengan cara memanfaatkan berbagai media aplikasi yang sedang naik daun atau viral di negara ini yang tentunya dapat menghasilkan uang seperti aplikasi Youtube dan Tiktok. Kedua aplikasi tersebut sangat memungkinkan meraup keuntungan yang dapat dimanfaatkan oleh berbagai instansi di dunia pendidikan yang nantinya bisa bermanfaat untuk membantu para siswa yang terkendala ekonomi saat pembelajaran online .
\end{abstract}

Kata Kunci: Youtube, Tiktok, Pembelajaran Online

\begin{abstract}
In accordance with the Circular of the Minister of Education and Culture Number 4 of 2020 concerning the implementation of education policies in the emergency period of the spread of COVID 19, he advises to carry out the learning process from home through online learning, the readiness of service providers and students is a demand for the implementation of online learning. Of course no one wants this all to happen. However, for humanity above all else, this needs to be done well so that we are all immediately free from the Covid-19 pandemic. The role of millennials should be very intensely needed in creating ideas and breakthroughs to stabilize all sectors during a pandemic like today. Therefore, the authors try to provide an idea that might be used as a solution in dealing with problems especially in the economic sector and the education sector. With the OKE MAS program (Optimizing E-learning Activities to Be Active and Soluctive) by utilizing various media applications that are on the rise or viral in this country which of course can generate money such as the Youtube and Tiktok
\end{abstract}


applications. Both applications are very possible to reap benefits that can be used by various institutions in the world of education which can later be useful to help students who are constrained by the economy when learning online.

Keywords: Youtube, Tiktok, Online Learning

\section{Pendahuluan}

Pendidikan merupakan tonggak perubahan suatu bangsa. Banyak artikel maupun jurnal juga yang menuliskan tentang bagaimana pentingnya pendidikan terhadap kemajuan sebuah negara. Dan tentu sangat bisa disimpulkan bahwa kesejahtraan disuatu negara dapat dilahat dari kemajuan pada dunia pendidikan di negara tersebut. Namun pada masa saat ini yaitu pandemi Covid-19 semua sektor seakan lumpuh akibat skema yang diberlakukan di tiap-tiap sektor dengan diberlakukannya pembatasan sosial bersekala besar yang telah dilakukan sejak awal tahun 2020 hingga saat ini. Imbas dari pandemi inipun berdampak pula pada sektor ekonomi. Banyak perusahaan yang gulung tikar. Sekolah sekolah sejak awal bulan Maret 2020 serentak resmi di tutup di Indonesia.

Sesuai dengan Surat Edaran Mendikbud Nomor 4 Tahun 2020 tentang pelaksanaan kebijakan pendidikan dalam masa darurat penyebaran Covid-19 mengajurkan untuk melaksanakan proses belajar dari rumah melalui pembelajaran daring, kesiapan dari pihak penyedia layanan maupun siswa merupakan tuntutan dari pelaksanaan pembelajaran daring. Atas kemanusian diatas segalanya, hal ini perlu di berlakukan dengan baik agar kita semua segera terbebas dari pandemi Covid19. Selain sektor pendidikan tentunya sektor yang paling terdampak atas lumpuhnya berbagai aktivitas adalah sektor ekonomi. Maka sudah tugas kita bersama untuk tetap menstabilkan tatanan negara agar tidak terjadi krisis ekonomi seperti di tahun-tahun sebelumnya yang dapat menghancurkan bahkan menyebabkan kerusuhan dimana-mana.
Sudah seharusnya peran milenial sangat intens diperlukan dalam menciptakan ide-ide dan trobosan untuk menstabilkan segala sektor saat masa pandemi seperi saat ini. Oleh karenanya gagasan yang mungkin bisa dijadikan solusi dalam mangatasi masalah saat ini kususnya dalam sektor ekonomi maupun sektor pendidikan yaitu program OKE MAS (Optimalisasi Kegiatan E-learning Menjadi Aktif dan Soluktif).

Pembelajaran Online atau Elearning yang banyak dinilai kurang efektif dan efisien tentu menjadi problematika baru saat kondisi pandemi. Dengan program OKE MAS kita dapat memanfaatkan berbagai media aplikasi yang sedang naik daun atau viral di negara ini yang tentunya dapat menjadi media pembelajaran yang lebih aktif dan disukai oleh kebanyakan siswa di sekolah. Selain itu kita juga dapat menghasilkan uang seperti pada aplikasi Youtube dan Tiktok. Kedua aplikasi tersebut sangat memungkinkan menjadi penghasilan tambahan yang dapat dimanfaatkan oleh berbagai instansi di dunia pendidikan yang nantinya bisa bermanfaat untuk membantu para siswa yang terkendala ekonomi saat pembelajaran online .

\section{Metode}

Pada penelitian ini dilakukan metode literature atau studi pustaka, karena pada dasarnya di masa pandemi sedikitnya berdampak pada terbatasnya ruang gerak dalam melakukan berbagai riset lapangan. Riset pustaka ini kegiatannya hanya pada pengumpulan bahan-bahan koleksi pustaka saja tanpa memerlukan riset lapangan, dengan demikian data-data yang dihasilkan pada penelitian ini merupakan serangkaian 
Jurnal Edumaspul, 4 (2), Year 2020 - 392

(Rudi Haryadi, Mochamad Wildan Al'ayubi)

kegiatan yang berkenaan dengan metode pengumpulan data pustaka, membaca dan mencatat serta mengolah bahan penelitian.

Data -data yang didapatkan merupakan data yang diambil dari berbagai sumber literature seperti buku, website , maupun penelitian terdahulu, yang kemudian dikembangkan dan dikaitkan dengan penelitian saat ini yaitu mengetahui bagaimana program OKE MAS ini apakah bisa digunakan dalam upaya peningkatan kualitas pendidikan di masa pandemi covid19 ini.

\section{Hasil dan Pembahasan}

Kemunculan Covid-19 merubah tatanan kehidupan pada berbagai aspek di dunia, termasuk aspek ekonomi. Salah satunya adalah negara Indonesia. Perekonomian Indonesia mengalami keterpurukan akibat adanya Covid-19 seperti yang ditunjukan pada Gambar 1 .

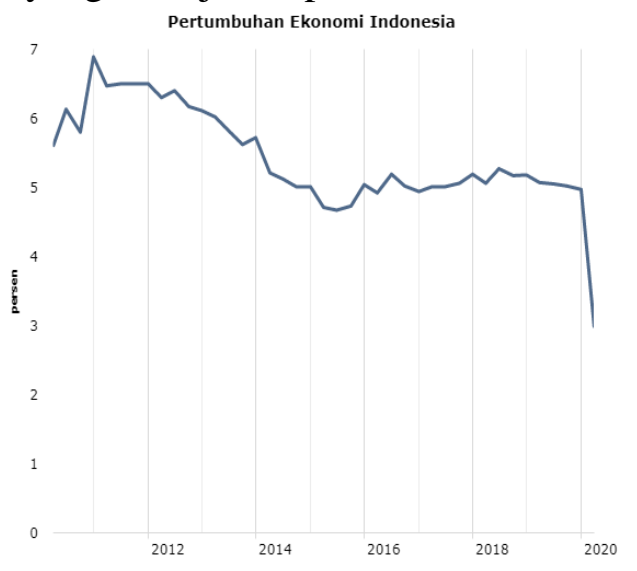

Gambar 1. Pertumbuhan ekonomi Indonesia selama pandemi (Alika, 2020)

Berdasarkan Gambar 1, perekonomian Indonesia menurun sangat signifikan, dimana dari 5,5\% menjadi $3 \%$ dari awal 2020 sampai saat ini. Hal ini diakibatkan oleh banyaknya karyawan yang dirumahkan atau bahkan terkena PHK. Kementerian keuangan mencatat, setidaknya ada lebih dari 1,5 juta jiwa pekerja telah dirumahkan dan terkena PHK. Dari angka tersebut 90 persen dirumahkan dan 10 persen sisanya terkena PHK sehingga berdampak pada pemasukan ekonomi setiap keluarga yang dapat menyebabkan menurunnya kesejahteraan keluarga. Hal ini pula yang menyebabkan Indonesia berada diambang resesi.

Pada saat ini pula Indonesia dihadapkan dengan polemik baru yang timbul akibat pandemi. Tidak hanya sektor ekonomi yang mengalami perubahan yang signifikan. Berbagai sektor kehidupan . Imbas dari pandemi inipun berdampak pula pada sektor pendidikan. Sekolah sekolah sejak awal bulan Maret 2020 serentak resmi di tutup di Indonesia dan belum pula menemui titik terang kapan bisa kbali normal. Sesuai dengan Surat Edaran Mendikbud Nomor 4 Tahun 2020 tentang pelaksanaan kebijakan pendidikan dalam masa darurat penyebaran Covid-19 mengajurkan untuk melaksanakan proses belajar dari rumah melalui pembelajaran daring, kesiapan dari pihak penyedia layanan maupun siswa merupakan tuntutan dari pelaksanaan pembelajaran daring.

Pembelajaran daring memerlukan perangkat pendukung seperti komputer, gawai, dan alat bantu lain sebagai perantara yang tentu saja harus terhubung dengan koneksi internet. Data stastistika 2019 menunjukkan penggunaan internet di Indonesia pada tahun 2018 sebanyak 95,2 juta, tumbuh $13,3 \%$ dari 2017 yang sebanyak 84 juta pengguna, pada tahun berikutnya penggunaan internet di Indonesia akan semakin meningkat dengan rata-rata pertumbuhan sebesar $10,2 \%$ pada periode 2018-2023. Dewasa ini, Indonesia telah memasuki revolusi industri 4.0 dimana masyarakat dituntut untuk dapat beradaptasi dengan perkembangan teknologi yang begitu pesat. Akan tetapi masyarakat Indonesia belum andal dalam menggunakan teknologi. Di Indonesia sendiri bahkan bisa dikatakan hanya segelintir orang yang mengenal revolusi industri 4.0, seperti kalangan akademisi yang melek akan kemajuan zaman, pebisnis yang mempunyai kepentingan dalam 
keberlangsungan usahanya, juga para pemangku kebijakan publik (Ucu, 2019). Oleh karena itu, banyak masyarakat yang belum siap ketika dihadapkan dengan kondisi pandemi yang mengharuskan digitalisasi secara menyeluruh. Akibatnya, perekonomian Indonesia semakin terpuruk.

Sementara itu, dunia sudah dihadapkan dengan adanya isu Society 5.0 yaitu konsep masyarakat yang berpusat pada manusia. Konsep ini di ciptakan oleh Jepang yang di ungkapkan oleh perdana menteri jepang pada 21 Januari 2019. Hal yang melatarbelakangi lahirnya adalah perkembangan teknologi yang begitu pesat, termasuk adanya kehadiran robot dengan kecerdasan yang dianggap dapat menggantikan peran manusia. Oleh sebab itu, perlu adanya keseimbangan antara peran manusia dengan perkembangan teknologi yang ada. Melalui Society 5.0, masyarakat diharapkan lebih siap menghadapi tantangan baru dan dapat mengevaluasi berbagai kekurangan pada revolusi industri 4.0.

Dengan melaksanakan pembelajaran dari rumah secara daring, guru dituntut untuk lebih inovatif dalam menyusun langkah-langkah pembelajaran. Perubahan cara mengajar ini tentunya membuat guru dan peserta didik beradaptasi dari pembelajaran secara tatap muka dikelas menjadi pembelajaran daring (Mastuti, dkk, 2020). Oleh karenanya sudah seharusnya guru harus lebih aktif dan mencari solusi agar kalangan siswa yang saat ini lebih tertarik dengan media sosial ketimbang pembelaran daring ini kembali melihat dan antusias dalam proses pembelajaran. Seperti memanfaatkan apa yang sedang digaungi para anak -anak, remaja, dan sebagian besar masyarakat Indonesia untuk dijadikan sebagai jalan keluar dari polemik pada pembelajaran daring ini.

Dengan berbagai permasalahan yang tengah dihadapi oleh seluruh lapisan masyarakat saat ini. Peran mahasiswa sangat diharapkan hadir sebagai faktor pembeda untuk dapat mengatasi berbagai masalah dan mengembalikan kestabilan perekonomian Indonesia. Opsi yang mungkin bisa digunakan mahasiswa untuk menghadapi keterpurukan ekonomi sekaligus menjembatani masyarakat untuk siap mengahadapi Society 5.0 yaitu dengan sebuah program OKE MAS (Optimalisasi Kegiatan E-learning Menjadi Aktif dan Soluktif). Dengan program OKE MAS kita dapat memanfaatkan berbagai media aplikasi yang sedang naik daun atau viral di negara ini yang tentunya dapat menjadi media pembelajaran yang lebih aktif dan disukai oleh kebanyakan siswa di sekolah dengan menghadirkan fitur menarik didalamnya seperti . Selain itu kita juga dapat menghasilkan uang seperti pada aplikasi Youtube dan Tiktok. Kedua aplikasi tersebut sangat memungkinkan menjadi penghasilan tambahan yang dapat dimanfaatkan oleh instansi di dunia pendidikan yang nantinya bisa bermanfaat untuk membantu para siswa yang terkendala ekonomi saat pembelajaran online .

Hadirnya aplikasi TikTok memang menambah keunikan dan keragaman dalam dunia media sosial di Indonesia. Aplikasi satu ini tentunya memiliki kelebihan yang membedakannya dengan aplikasi lain. Dengan kelebihan itulah menjadikan TikTok seolah sulit tergantikan oleh platform sejenis yang berusaha menyaingi kepopularitasan platform media sosial ini. Beberapa kelebihan tersebut yaitu durasi video 15 Detik, filter beragam, dapat dilihat oleh semua pengguna tanpa perlu daftar akun dan menambahkan musik pilihan. TikTok juga memiliki berbagai manfaat dan kelebihan yang menjadikannya selalu membuat masyarakat penasaran. Apalagi aplikasi ini juga menyediakan pilihan musik dan filter yang up todate sehingga membuat para penggunanya tidak cepat bosan. TikTok juga bisa membantu memperoleh hiburan sekaligus uang yang tentunya membuat kita tidak perlu ragu 
memanfaatkan TikTok untuk meningkatkan motivasi belajar siswa namun juga dapat memberi keuntungan dari sekedar hanya melihat saja.

Selain TikTok aplikasi yang sedang terus diakses oleh masyarakat Indonesia kebanyakan adalah Aplikasi YouTube. Sudah banyak memang media pembelajaran dan konten pendidikan yang ada pada YouTube , namun karena kurang terstruktur dan sistematis menyebabkan pamor dari konten pendidikan tersebut kalah saing dengan konten hiburan lainnya. Penghasilan youtuber sekitar 1 USD per 1000 views. Namun angka tersebut tidak bisa dijadikan patokan karena itu hanya berlaku untuk pasar Amerika saja, dan tentu saja semuanya bergantung kepada jumlah klik iklannya. SelainSelain itu, jenis konten pun memegang peran penting untuk menentukan harga per klik. Umumnya, topik YouTube yang mendapat bayaran klik cukup mahal, adalah topik yang potensi iklannya banyak. Misalnya topik tentang smartphone, musik, kamera, dan lainnya.

Indikator yang biasa dipakai untuk menghitung pendapatan Youtube adalah Revenue per Impression (RPM). Yaitu keuntungan yang Anda dapatkan dari 1.000 penayangan iklan dari video Youtube Anda. Indonesia memiliki RPM yang rendah jika dibanding dengan negara lain. Apalagi jika dibandingkan Amerika, jauh banget! Bayaran per 1.000 views-nya bisa mencapai 1-7 USD. Untuk memperkirakan jumlah penghasilan Youtuber Indonesia kita bisa mendapatkan sekitar 7.000 rupiah per 1.000 tayangan iklan. Jadi jika video Anda mendatangkan 1 juta views iklan maka pendapatan yang mungkin diperoleh sekitar 550 USD atau sekitar 7 jutaan. Angka ini adalah perhitungan kasar namun lebih mendekati kenyataan dibandingkan menggunakan RPM 1 USD per 1.000 tayangan iklan.

Jika itu dimanfaatkan oleh instansi pendidikan darurat pandemi ini, dengan menciptakan suatu akun yang harus di akses maupun di subscribe oleh setiap siswa yang ada di Indonesia , maka sudah sangat jelas bahwa akun milik instansi tersebut mendapatkan penghasilan yang cukup besar yang bisa kembali di rasakan oleh para siswa dalam menunjang masa sekolah di masa pandemi saat ini. TentuTentu sekema ini tidak bisa berjalan tanpa adanya kekompakan dari berbagai pihak dari tingkatan atas yaitu pemerintah sampai ke siswa tiap sekolah yang harus sama sama menganggap bahwa sekema ini sangat penting untuk dilakukan, karena bisa berdampak baik terutama pemerataan proses pendidikan, karena uang yang dihasilkan dari sekema ini singkatnya juga dapat digunakan untuk membangun fasilitas pembelajaran dan pemerataan jaringan internet di pelosok - pelosok daerah dengan pemasangan Wi-Fi. Atau untuk diberikan kepada masyarakat yang terdampak pandemi dengan tidak hanya menggunakan anggaran saja tapi juga bisa menghasilkan anggaran yang nantinya dapat kembali lagi di gunakan untuk kepentingan rakyat.

\section{Simpulan}

Program OKE MAS dianggap bisa dijadikan opsi untuk meningkatkan mutu pendidikan dan juga meningkatkan kondisi ekonomi kala pandemi. Selain dapat meningkatkan motivasi belajar anak karena dianggap relevan dengan kebutuhan dan keinginan para sisiwa yang kini lebih intens menggunakan aplikasi tiktok dan YouTube. Dari kedua contoh aplikasi tersebut dapat menghasilkan uang dengan cara yang hampir sama, yaitu dengan memanfaatkan Viewers maupun Pengikut / Subscribe. Oleh karena itu sangat memungkinkan untuk mendapatkan penghasilan tambahan dalam sektor pendidikan dikala pembelajaran online seperti sekarang, melihat jumlah siswa dari tiap tingkatan yang ada di seluruh indonesia sangat banyak dari tingkat SD, SMP, \& SMA. 
Jurnal Edumaspul, 4 (2), Year 2020 - 395

(Rudi Haryadi, Mochamad Wildan Al'ayubi)

Jadi akun yang dikelola oleh instansi pendidikan harus di dukung oleh berbagai pihak. Para guru juga harus dituntut untuk menjadi pengawas dalam pelaksanaan skema ini. Karena siswa maupun wali siswa akan merasa bahwa sekema ini merupakan hal yang wajib dilakukan apabila tiap gurub dari tiap sekolah yang ada di Indonesia tela serempak menerapkan dan juga memberikan pembelajaran maupun contoh materi suatu pelajaran diambil dari akun Tiktok maupun Youtube yang di kelola oleh dinas pendidikan.

Agar para siswa di Indonesia juga tidak melulu menggunakan kedua aplikasi diatas yang hanya di pergunakan untuk hal hal yang kurang baik, seperti hanya untuk melihat video-video game, kartun , berjoget,menonton film korea, dan hiburanhiburan lainnya. Oleh karenanya penulis rasa ini bisa menjadi solusi untukk pendapatan negara dimasa pandemi karena dengan memanfatkan apa yang selama ini viral dan sangat sering di gunakan oleh semua orang.

\section{Daftar Pustaka}

[1] Kemendikbud RI.(2020).Edaran Tentang Pencegahan Wabah COVID 19 di Lingkungan Satuan Pendidikan seluruh Indonesia. Effendi, S. (1982).
Unsur-unsur penelitian ilmiah. Dalam Masri Singarimbun (Ed.). Metode penelitian survei. Jakarta: LP3ES.

[2] Kementerian Dalam Negeri.(2020). Pedoman Umum Menghadapi Pandemi COVID 19 Bagi Pemerintah Daerah .126.https://doi.org/10.1017/CBO9781107 415324.004

[3] Rizky, A. 2020. Terdampak Pandemi, Ekonomi Indonesia Dinilai Sudah di Ambang Resesi. https://katadata.co.id/ekarina/finansial/5f $110 \mathrm{bf} 43688 \mathrm{~d} /$ terdampak-pandemiekonomi-indonesia-dinilai-sudah-diambang-resesi

[4] Riyana, C, \& Pd,M. (n.d) Konsep Pembelajaran Online

[5] Jannah . R Pembelajaran Daring Fisika Siswa SMA / https://ummaspul.ejournal.id/maspuljr/article/view/842

\section{Profil Penulis}

Mochamad Wildan Al'ayubi, Seorang yang meniduri bumi pertama kali pada 10 Juni 2000 ini sangat hobi menaklukkan tantangan tantangan baru. Suka ketenangan di gunung, hutan, dan dilautan karena dikeramaian lebih banyak kepalsuan. Memiliki cita cita secepatnya presiden setidaknya untuk negara kecil yang sering disebutnya keluarga kecil Al'ayubi. Saat ini sedang menempuh pendidikan di Universitas Sultan Ageng Tirtayasa. Jurusan Pendidikan Fisika. 